\title{
Ka KERTHA WICAKSANA

\section{Rekonstruksi Hukum Adat Terhadap Pelanggaran Protokol Kesehatan Selama Pandemi Covid-19 di Desa Adat Kota Tabanan}

\author{
Diah Gayatri Sudibya, Dessy Lina Oktaviani Suendra* dan Kade Richa Mulyawati \\ Universitas Warmadewa, Denpasar, Bali-Indonesia \\ *dessysuendra@gmail.com
}

Published: 25/07/2021

How To Cite:

Sudibya, D, G., Suendra, D, L, O., Mulyawati, K, R. (2021). Rekonstruksi Hukum Adat Terhadap Pelanggaran

Protokol Kesehatan Selama Pandemi Covid-19 di Desa Adat Kota Tabanan. KERTHA WICAKSANA:

Sarana Komunikasi Dosen dan Mahasiswa. 15 (2). Pp 99 - 107. https://doi.org/10.22225/kw.15.2.2021.99-107

\begin{abstract}
Abstrak
Semakin tingginya jumlah masyarakat yang terkena covid-19 ini maka pemerintah terus gencar mengeluarkan peraturanperaturan guna menekan pertumbuhan kasus baru dan meminimalisir klaster baru penyebaran covid-19. Desa Adat Kota Tabanan yang telah dicatatkan sebanyak dua kali masuk dalam zona merah penyebaran Covid-19 menyikapi permasalahan pandemi Covid-19 yang semakin merajarela ini dengan membentuk suatu perarem atau aturan adat yang berlaku di Desa Adat setempat yakni Perarem Adat Kota Tabanan Nomor 5 Tahun 2020 tentang Pengaturan Pencegahan dan Pengendalian Gering Agung Covid-19. Perarem ini telah disahkan pada tanggal 19 Juli 2020 dan telah disosialisasikan secara bertahap ke banjarbanjar adat. Adapun tujuan dari dibentuknya perarem ini sendiri adalah untuk memustus rantai penyebaran Covid-19 dan meningkatkan kedisiplinan dari masyarakat desa dikarenakan dalam perarem ini juga disertakan sanksi denda. adapun permaslahan yang akan dikaji adalah bagaimanakah pengaturan hukum mengenai pelanggaran protokol kesehatan selama pandemi Covid-19 di desa adat kota Tabanan? dan bagaimanakah rekonstruksi hukum adat yang ideal dalam menanggulangi pelanggaran protokol kesehatan selama pandemi Covid-19 di desa adat kota Tabanan ?. metode yang digunakan dalam penelitian ini adalah metode hukum empiris dan dikaji dengan pendekatan perundang-undangan. Hasil dari penelitian ini adalah desa adat kota tabanan telah memiliki Pararem Desa Adat Kota Tabanan Nomor 5 Tahun 2020 yang di dalamnya memuat sanksi-sanksi denda bagi pelanggar protocol kesehatan hanya saja masih banyak masyarakat yang tidak mentaati peraturan tersebut. Mengatasi hal demikian maka diperlukan adanya rekonstruksi norma agar tidak adanya celah-celah yang dapat dimanfaatkan oleh pelanggar protocol kesehatan.
\end{abstract}

Kata Kunci: Hukum; Protokol Kesehatan; Rekontrusi

\begin{abstract}
The higher the number of people affected by COVID-19, the government continues to aggressively issue regulations to suppress the growth of new cases and minimize new clusters of the spread of COVID-19. The Tabanan City Traditional Village, which has been listed twice as being in the red zone for the spread of Covid-19, is responding to the increasingly rampant Covid-19 pandemic problem by forming a perarem or customary rules that apply to the local Traditional Village, namely the Tabanan City Customary Regulation Number 5 of 2020 on the Regulation of Prevention and Control of Gering Agung Covid-19. This Perarem was ratified on July 19, 2020 and has been gradually socialized to the traditional banjars. The purpose of the formation of this regulation itself is to break the chain of the spread of Covid-19 and increase the discipline of the village community because this regulation also includes fines. As for the problem that will be studied, how are the legal arrangements regarding violations of health protocols during the Covid-19 pandemic in the traditional village of Tabanan city? and how is the ideal reconstruction of customary law in overcoming violations of health protocols during the Covid-19 pandemic in the traditional village of Tabanan city?. The method used in this research is the empirical legal method and is studied with a statutory approach. The results of this study are the traditional village of Tabanan City already has the Pararem of the Traditional Village of Tabanan City Number 5 of 2020 which includes fine sanctions for violators of the health protocol, only that there are still many people who do not comply with these regulations. To overcome this, it is necessary to reconstruct norms so that there are no gaps that can be exploited by health protocol violators.
\end{abstract}

Keywords: Law; Health Protocol; Recontrusion 


\section{PENDAHULUAN}

Pada awal tahun 2020 Indonesia bahkan semua negara di dunia dikagetkan dengan munculnya virus baru yang efeknya sangat menakutkan yaitu bisa membawa kematian, virus ini disebut oleh para ahli dengan istilah COVID19 yang merupakan singkatan dari Corona Virus Desease 2019 yakni dijelaskan sebagai penyakit yang disebabkan oleh infeksi virus Severe Acute Respiratory Syndrome Coronavirus 2 (SARSCoV -2) yang muncul pertama kali di kota Wuhan, China pada bulan Desember. Merebaknya virus Covid-19 ini menyebabkan tingkat penularan bahkan mencapai kematian semakin meningkat dari hari ke hari hal ini menempatkan seluruh dunia tentu saja termasuk Indonesia ke dalam masa Pandemi, hal ini sesuai dengan keputusan WHO yang dikeluarkan tanggal 11 Maret 2020 yang menaikan status tingkat penyebaran status ini dan menghimbau seluruh negara selalu siaga.

Masa pandemi yang disebabkan oleh wabah Covid-19 tidak dapat dipungkiri membawa dampak yang amat sangat besar bagi seluruh negara yang sedang terjangkit oleh wabah virus ini. Ketidakstabilan akibat virus ini dirasakan dari segala sector yang paling parah adalah sector ekonomi. Masyarakat mendapatkan cobaan yang sangat berat hal ini dikarenakan himbauan pemerintah kepada masyarakat untuk di rumah saja, sekolah dan perkantoran menerapkan wfh dan lebih parahnya lumayan banyak pekerja yang dirumahkan hal ini sudah pasti membawa dampak yang besar bagi kehidupan mereka.

Melihat kondisi yang berubah drastis 180 derajat di masa pandemi ini tidak dapat dipungkiri bahwa Bali menjadi salah satu Provinsi yang terkena dampat sangat besar selama Pandemi Covid-19 ini. Tidak hanya masalah kesehatan dan perekonomian tetapi juga berdampak terhadap pariwisata yang notabene sebagai sumber pendapatan utama bagi Provinsi Bali. Usaha pemerintah propinsi Bali untuk mencegah makin merebaknya virus ini adalah dengan gencar mengeluarkan himbauan untuk selalu menerapkan protokol Kesehatan yaitu rajin mencuci tangan, selalu menggunakan masker di setiap kegiatan, dan menjaga jarak dengan orang lain apabila sedang berada di keramaian. Di tempat-tempat umum seperti misalnya di pasar, swalayan, rumah makan, kantor pemerintahan maupun swasta, dan tempat public lainnya juga disediakan tempat cuci tangan dan selalu memastikan orang-orang yang berkunjung untuk menggunakan hand sanitizer sebelum memasuki tempat public tersebut, serta tak lupa dilakukan pengukuran suhu tubuh.

Usaha-usaha yang dilakukan pemerintah tersebut baik dari himbauan di rumah saja dan gencarnya peringatan untuk selalu menerapkan protokol Kesehatan nampaknya tidak juga dapat menekan lajunya tingkat penularan virus Covid19 ini. Terlihat dari tingkat penyebarannya yang terus meningkat secara signifikan tiap bulannya dari sejak merebaknya virus ini. Di Bali sendiri pencegahan terhadap penyebaran virus ini masih sangat kurang, terlebih lagi pada bulan September salah satu kabupaten yang berada di Bali masuk zona merah yaitu kabupaten Tabanan. Juru bicara Satgas Penanganan Covid-19 Wiku Adisasmito mengungkapkan ada 38 kabupaten/kota yang mengalami perubahan dari risiko sedang (zona oranye) ke zona reisiko tinggi (zona merah) penularan Covid-19 yang mana kabupaten/kota yang dimaksud ini salah satunya adalah Tabanan (Sumber:bali.tribunnews.com). Perlu diketahui bahwa zonasi ini disusun berdasarkan tiga indicator yakni epidemologi, surveilans Kesehatan masyarakat, dan pelayanan Kesehatan. Dari tiga indicator tersebut pemerintah menetapkan zonasi merah (risiko tinggi), oranye (resiko sedang), kuning (resiko rendah), dari hijau (tanpa kasus). Kemudian pada bulan Oktober Kembali rilis berita yang menyatakan bahwa kota Denpasar dan Tabanan Kembali masuk zona merah penyebaran Covid-19. Status ini muncul lantaran terjadinya lonjakan kasus covid-19 sejak beberapa hari terakhir. (Sumber: radarbali.jawapos.com)

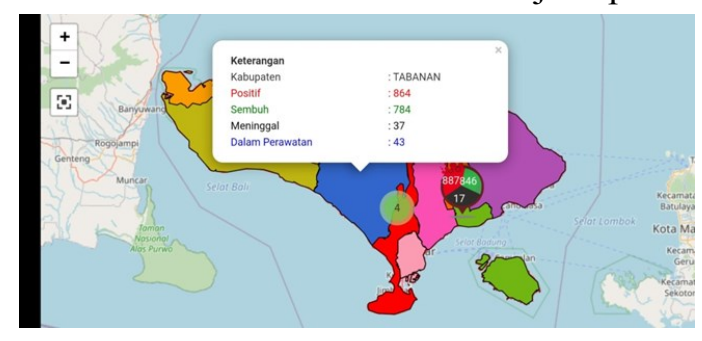


Semakin tingginya jumlah masyarakat yang terkena covid-19 ini maka pemerintah terus gencar mengeluarkan peraturan-peraturan guna menekan pertumbuhan kasus baru dan meminimalisir klaster baru penyebaran covid-19. Desa Adat Kota Tabanan yang telah dicatatkan sebanyak dua kali masuk dalam zona merah penyebaran Covid-19 menyikapi permasalahan pandemi Covid-19 yang semakin merajarela ini dengan membentuk suatu perarem atau aturan adat yang berlaku di Desa Adat setempat yakni Perarem Adat Kota Tabanan Nomor 5 Tahun 2020 tentang Pengaturan Pencegahan dan Pengendalian Gering Agung Covid-19. Perarem ini telah disahkan pada tanggal 19 Juli 2020 dan telah disosialisasikan secara bertahap ke banjarbanjar adat. Adapun tujuan dari dibentuknya perarem ini sendiri adalah untuk memustus rantai penyebaran Covid-19 dan meningkatkan kedisiplinan dari masyarakat desa dikarenakan dalam perarem ini juga disertakan sanksi denda.

Perarem ini mengatur beberapa perbuatan yang tergolong sebagai Tindakan pelanggaran protokol Kesehatan dan diikuti pula dengan sanksi denda yang jumlahnya beraneka ragam sesuai dengan pelanggaran yang dilakukan. Adapun perbuatan yang dianggap sebagai pelanggaran protokol Kesehatan di masa pandemi Covid-19 ini adalah tidak menggunakan masker pada saat keluar rumah, melanggar jam buka atau tutup warung tradisional dan took modern, melanggar jam malam yang telah ditentukan begitu pula apabila bertamu melewati jam yang telah ditentukan yg mana apabila ini terjadi maka yang bertamu maupun tuan rumah akan dikenakan sanksi denda, dan yang terakhir apabila terlihat ada masyarakat yang keluar setelah lewat waktu yang telah ditentukan maka diwajibkan membayar denda. Selanjutnya uang denda yang diperoleh akan masuk ke Desa Adat Kota Tabanan dan akan digunakan sebagai subsidi untuk kegiatan yang dilakukan Satgas Gotong Royong. (Sumber baliexpress.jawapos.com)

Selain di kota Tabanan sanksi denda sebagai hukuman pada pandemi Covid-19 juga diterapkan di salah satu desa adat yang berada di kota Tabanan yaitu desa adat Blumbang, Kecamatan Kerambitan yang mana terbit perarem yg isinya menegaskan setiap warga desa adat setempat yang keluyuran sedangkan kepada mereka wajib menjalani (terutama bagi PMI) dapat dikenakan denda (sanksi adat) menghaturkan upacara/ sesajen Guru Piduka ditambah denda berupa uang sebesar Rp. 500.000 (Lima Ratus Ribu Rupiah) (APHA Indonesia, 2020). Terlihat dalam perarem desat adat Blumbang ini hukuman yang diberikan selama masa pandemi selain sanksi denda dijatuhkan pula hukuman melangsungkan upacara adat demi mengembalikan lingkungan yang diangap telah tercemar yang dalam hal ini karena virus Covid-19.

Sayangnya, seiring dengan berjalannya perarem ini, tingkat masyarakat yang terinfeksi virus Covid-19 di desa adat kota Tabanan masih tinggi dan juga masih terjadi pelanggaran protokol kesehatan. Berdasarkan uraian tersebut maka dalam artikel ini akan membahas mengenai bagaimanakah pengaturan hukum mengenai pelanggaran protokol kesehatan selama pandemi Covid-19 di desa adat kota Tabanan? dan bagaimanakah rekonstruksi hukum adat yang ideal dalam menanggulangi pelanggaran protokol kesehatan selama pandemi Covid-19 di desa adat kota Tabanan?

\section{METODE}

Penelitian yang dipergunakan dalam penyusunan artikel ini adalah tipe penelitian empiris. Penelitian empiris menurut Soerjono Soekanto disebut juga penelitian hukum sosiologis, yang terdiri dari penelitian terhadap indentifikasi hukum (tidak tertulis) dan penelitian terhadap efektifitas hukum. (Soekanto, 2007) Dalam penelitian ini dipergunakan pendekatan perundang-undangan (statue approach), pendekatan konsep (conceptual approach) dan pendekatan analitis (analyicialapproach). Data yang digunakan dalam penyusunan skripsi ini terdiri dari 2 (dua) jenis yaitu: Data Primer dan Data Sekunder. Teknik Pengumpulan data yang digunakan dalam penelitian ini adalah:Teknik wawancara, Teknik Studi Dokumen dan Teknik Observasi/Pengamatan.

\section{III.HASIL PENELITIAN DAN PEMBAHASAN}

\section{Pengaturan Hukum Mengenai Pelanggaran Protokol Kesehatan Selama Pandemi Covid-19 Di Desa Adat Kota Tabanan}

Indonesia adalah Negara hukum. Ini adalah istilah yang sering digaungkan disetiap kesempatan membicarakan masalah hukum di Indonesia. Setiap Negara yang menganut prinsip Negara hukum pasti tidak lepas dari asas legalitas sebagai persyaratan dalam segala bentuk tindakan pemerintahan yang harus didasarkan atas perundang-undangan yang sah dan tertulis (Utrecht, 1962). Dengan pernyataan demikian 
maka dapat dikatakan peraturan perundangundangan tertulis harus dirumuskan dan diundangkan terlebih dahulu atau haruslah ada sebelum tindakan atau perbuatan administrative dilanggar maka setiap perbuatan atau tindakan administrative badan/pejabat Negara harus didasarkan aturan atau rules and procedures.

Dalam konstitusi ditegaskan bahwa negara Indonesia adalah Negara Hukum (Rechtsstaat), bukan Negara Kekuasaan (Machtsstaat). Di dalamnya terkandung pengertian adanya pengakuan terhadap prinsip supremasi hukum dan konstitusi, dianutnya prinsip pemisahan dan pembatasan kekuasaan menurut sistem konstitusional yang diatur dalam Undang-Undang Dasar, adanya jaminan-jaminan hak asasi manusia dalam Undang-Undang Dasar, adanya prinsip peradilan yang bebas dan tidak memihak yang menjamin persamaan setiap warga negara dalam hukum, serta menjamin keadilan bagi setiap orang termasuk terhadap penyalahgunaan wewenang oleh pihak yang berkuasa (Jimly Asshiddiqie, h 55-52). Dengan demikian, dalam paham negara hukum, hukumlah yang memegang kekuasaan tertinggi dalam penyelenggaraan negara. Oleh karena itu, badan atau pejabat negara dalam melakukan suatu tindakan, harus berdasarkan peraturan perundang-undangan.

Pandemi Covid-19 memiliki dampak yang sangat besar dalam kehidupan masyarakat terutama dalam sector sosial kesehatan, dan ekonomi. Dalam 1 tahun terakhir ini, meski telah diberlakukan adaptasi kebiasaan baru, penyebaran wabah COvid-19 terus melonjak naik. Seiring dengan hal tersebut, pemerintah telah mengeluarkan berbagai produk hukum guna menekan dan mengatasi penyebaran virus Covid19 ini. Sedangkan untuk Provinsi Bali sendiri terdapat banyak aturan mengenai penanganan Covid-19 seperti:

Keputusan Bersama Gubernur Bali, Majelis Desa Adat Provinsi Bali Nomor 472/1571/PPDA/ DPMA,05/SK/MDA-PROV BALI/III/2020 Tahun 2020 tentang Pembentukan Satuan Tugas Gotong Royong Pencegahan CPvid-19 Berbasis Desa Adat di Bali

Peraturan Gubernur Bali Nomor 10 Tahun 2021 tentang Penerapan Disiplin Dan Penegakan Hukum Protokol Kesehatan Sebagai Upaya Pencegahan Dan Pengendalian Corona Virus Disease 2019 Dalam Tatanan Kehidupan Era Baru
Keputusan Wali Kota Denpasar Nomor 188.45/958/HK/2020 Tahun 2020 tentang Pembentukan Satuan Tugas Penanganan Corona Virus Disease 2019 (Covid-19) Kota Denpasar

Keputusan Wali Kota Denpasar Nomor 188.45/959/HK/2020 Tahun 2020 Pembentukan Satuan Tugas Penanganan Corona Virus Disease 2019 (Covid-19) Kecamatan

Keputusan Wali Kota Denpasar Nomor 188.45/961/HK/2020 Tahun 2020 Pembentukan Satuan Tugas Penanganan Corona Virus Disease 2019 (Covid-19)

Dengan beragamnya aturan hukum mengenai protokol kesehatan untuk pandemi Covid-19 di Provinsi Bali ini menunjukkan bahwa kesigapan pemerintah Provinsi Bali akan penyebaran virus ini. Adapun berdasarkan aturan tersebut diatas dalam melaksanakan tugas, satgas harus mematuhi protokol yang telah ditetapkan pemerintah yang meliputi lima hal yaitu protokol komunikasi, area pendidikan, area public dan transportasi, khususnya pintu masuk Indonesia dan protokol kesehatan.

Sejalan dengan aturan-aturan tersebut, desadesa pakraman di Provinsi Bali pun turut melakukan tindak lanjut dari kebijakan pemerintah melalui Perarem. Dalam substansinya, perarem dapat digolongkan dalam 3 golongan, yaitu (Sudantra \& Windia, 2011)

Pararem penyahcah awig, yaitu keputusankeputusan paruman yang merupakan aturan pelaksana dari awig-awig

Pararem ngele/ pararem lepas, yaitu keputusan paruman yang merupakan aturan hukum baru yang tidak ada landasannya dalam awig-awig tetapi dibuat untuk memenuhi kebutuhan hukum masyarakat

Pararem penepas wicara, yang berupa keputusan Paruman mengenari suatu persoalan hukum (perkara) tertentu, baik yang berupa sengketa maupun pelanggaran hukum (pararem penapas wicara).

Bertujuan membuat masyarakat patuh, dalam penerapannya apabila ada yang melanggar awigawig maupun perarem akan dikenakan sanksi. Sanksi tersebut dikenal dengan istilah pamidanda, mempunya tujuan untuk mengembalikan keseimbangan bila terjadi gangguan keseimbangan hubungan dalam aspek-aspek kewilayahan (palemahan), kemasyarakatan (pawongan), dan keagamaan (parahyangan). 
Pamidanda ini dalam literatur hukum lebih dikenal dengan sebutan sanksi adat. Secara umum sanksi adat ini terdiri dari tiga golongan, yaitu sanksi yang berkaitan dengan harta benda (uang atau barang), disebut artha danda; sanksi yang berkaitan dengan nestapa jiwa atau fisik disebut dengan jiwa danda; serta sanksi yang berkaitan dengan upaya pengembalian keseimbangan alam gaib (niskala) disebut dengan panyangaskara danda. (Parwata, A, A, 2007)

Dari berbagai pararem desa adat yang sudah membuat dan mengesahkan pararem yang diatur diantaranya:

Ketentuan umum, pengertian tentang desa adat, banjar adat, prajuru desa dan perarem.

Maksud dan tujuan dibuatnya pararem covid19, yaitu dalam rangka pencegahan dan pengendalian Covid-19

Ruang lingkup pencegahan dan pengendalian, meliputi: perilaku hidup sehat, pembatasan kegiatan berbasis desa adat, satuan tugas gotong royong, penanganan kasus terpapar, ngeneng dan ngeneing desa adat, sanksi dan ketentuan penutup.

Masyarakat Bali berharap, dengan adanya pararem yang bertujuan untuk mencegah dan mengendalikan Covid-19 ini kedepannya dapat mengembalikan kehidupan masyarakat seperti sebelumnya atau sedia kala.

Desa Adat Kota Tabanan juga telah mengikuti intruksi dari Gubernur untuk membentuk pararem terkait pencegahan Covid-19, yaitu Pararem Desa Adat Kota Tabanan Nomor 5 Tahun 2020 tentang Pengaturan Pencegahan dan Pengendalian Gering Agung Covid-19 yang mulai berlaku 1 September 2020. Dalam perarem tersebut, telah diatur sejumlah ketegasan seperti diantaranya denda untuk warga yang tidak menggunakan masker, melanggar jam buka/tutup warung tradisional dan toko modern, hingga bertamu lewat jam yang telah ditentukan.

Untuk masyarakat yang tidak menggunakan masker akan didenda Rp 50 Ribu, untuk warung tradisional yang melanggar jam buka/tutup didenda Rp 100 ribu dan toko modern yang melanggar didenda maksimal $\mathrm{Rp} 500$ Ribu. Kemudian untuk warga yang bertamu tanpa tujuan yang jelas melewati jam akan didenda masing masing $\mathrm{Rp} 250$ ribu baik tuan rumah maupun yang bertamu. Terakhir, masyarakat yang keluyuran lewat jam tanpa tujuan yang jelas akan didenda Rp 250 ribu (Aryawan, 2020).

Berbicara mengenai suatu aturan hukum pastilah yang akan diukur adalah efektif atau tidak aturan atau norma hukum tersebut di masyarakat. Soerjono soekanto. Mengemukakan bahwa efektif atau tidaknya suatu hukum bergantung pada lima factor yaitu:

Faktor hukumnya sendiri (undang-undang).

Faktor penegak hukum, yakni pihak-pihak yang membentuk maupun menerapkan hukum.

Faktor sarana atau fasilitas yang mendukung penegakan hukum.

Faktor masyarakat, yakni lingkungan dimana hukum tersebut berlaku atau diterapkan.

Faktor kebudayaan, yakni sebagai hasil karya, cipta dan rasa yang didasarkan pada karsa manusia di dalam pergaulan hidup.

Hukum akan menjadi efektif jika tujuan keberadaan dan penerapannya dapat mencegah perbuatan-perbuatan yang tidak diinginkan dapat menghilangkan kekacauan. Hukum yang efektif secara umum dapat membuat apa yang dirancang dapat diwujudkan. Jika suatu kegelapan maka kemungkinan terjadi pembetulan secara gampang jika terjadi keharusan untuk melaksanakan atau menerapkan hukum dalam suasana baru yang berbeda, hukum akan sanggup menyelesaikan (H.S \& Nurbani, 2013).

Ketika berbicara sejauh mana efektivitas hukum maka kita pertama-tama harus dapat mengukur sejauh mana aturan hukum itu dimengerti atau tidak dimengerti dan ditaati atau tidak ditaati. Jika suatu aturan hukum dimengerti dan ditaati oleh sebagian besar target yang menjadi sasaran ketaatannya maka akan dikatakan aturan hukum yang bersangkutan adalah efektif. Kesadaran hukum dan ketaatan hukum merupakan dua hal yang sangat menentukan efektif atau tidaknya pelaksanaan perundangundangan atau aturan hukum dalam masyarakat. Kesadaran hukum, ketaatan hukum, dan efektivitas perundang-undangan adalah tiga unsur yang saling berhubungan. Sering orang mencampuradukan antara kesadaran hukum dan ketaatan hukum, padahal kedua itu meskipun sangat erat hubungannya, namun tidak persis sama. Kedua unsur itu memang sangat menentukan efektif atau tidaknya pelaksanaan perundangundangan di dalam masyarakat.

Berdasarkan uraian mengenai efektifitas 
hukum tersebut maka perlu ditelaah lebih mendalam apakah berbagai peraturan yang dibentuk untuk menanggulangi penyebaran virus covid-19 sudah sepenihnya efektif berlaku di masyarakat. Pengujian mengenai efektit atau tidak suatu aturan salah satu tujuannya adalah agar bisa diputuskan apakah aturan tersebut harus diubah atau dicabut dan diganti dengan yang baru.

\section{Rekonstruksi Hukum Adat Yang Ideal Dalam Menanggulangi Pelanggaran Protokol Kesehatan Selama Pandemi Covid-19 Di Desa Adat Kota Tabanan}

Seperti yang dijelaskan sebelumnya bahwa telah begitu banyak peraturan yang dikeluarkan pemerintah baik pusat maupun daerah yang mengatur tentang penanganan covid-19. Kota tabanan sendiri selain memiliki peraturan daerah tersendiri tetapi juga tetap tunduk pada peraturan yang dibentuk oleh pemerintah pusat seperti yang dijelaskan pada pembahasan pertama dan kota tabanan juga menjadikan aturan penangan covid 19 yang dibentuk oleh pemerintah provinsi Bali sebagai acuan dalam menekan penyebaran virus ini.

Berdasarkan peraturan hukum yang dibentuk oleh pemerintah pusat dan pemerintah Propinsi Bali tersebut, kota tabanan membentuk Pararem Nomor 5 Tahun 2020 tentang Pengaturan Pencegahan dan Pengendalian Gering Agung Covid-19 di Desa Adat Kota Tabanan. Pada pelaksanaanya, Pararem Nomor 5 Tahun 2020 tentang Pengaturan Pencegahan dan Pengendalian Gering Agung Covid-19 di Desa Adat Kota Tabanan telah mengalami pro dan kontra di media sosial terkait pemberian sanksi. Adapun denda yang dikenakan kepada masyarakat yang melanggar protokol kesehatan diantaranya, masyarakat yang tak menggunakan masker didenda Rp 50 ribu. Untuk warung tradisional yang melanggar jam buka/tutup lewat pukul 22.00 WITA didenda $\mathrm{Rp} 100 \mathrm{ribu}$ dan toko modern yang melanggar didenda maksimal $\mathrm{Rp}$ 500 ribu. Kemudian untuk warga yang bertamu tanpa tujuan yang jelas melewati jam 22.00 WITA masing-masing didenda $\mathrm{Rp} 250$ ribu baik bagi tuan rumah dan yang bertamu. Dan masyarakat yang keluyuran lewat jam 22.00 WITA tanpa tujuan yang jelas didenda Rp 250 ribu.

Masyarakat merasa diberatkan akan aturan tersebut karena masih banyak masyarakat yang harus berkerja atau pulang bekerja melewati jam malam yang telah ditetapkan tersebut. Apalagi selama Covid-19 ini perekonomian masyarakat Tabanan juga mengalami kesulitan sehingga apabila ditambah dengan pembatasan jam malam maka kesempatan mereka untuk mencari nafkah akan semakin terbatasi.

Selain masalah pro dan kontra ini, tingginya angka kasus positif Covid-19 di kota Tabanan membuat Pararem Nomor 5 tahun 2020 tentang Pengaturan Pencegahan dan Pengendalian Gering Agung Covid-19 ini seakan tidak efektif untuk mencegah penyebaran covid-19.

Untuk mencari tahu permasalahan kurang efektifnya aturan ini, peneliti berupaya untuk turun lansgung ke lapangan dan melakukan wawancara dengan masyarakat, yang tidak hanya tinggal di kota Tabanan, tetapi juga dengan masyarakat di beberapa desa di Tabanan untuk dimintakan pendapatnya terkait dengan kurang efektifnya aturan ini. Wawancara dilakukan dengan 20 orang yang berasal dari kota Tabanan serta dari desa adat lainnya di Tabanan yaitu dari Desa Adat Bongan Puseh, Desa Adat Kerambitan,

Berdasarkan hasil wawancara yang dilakukan tim peneliti bahwa sebagian besar masyarakat baik di kota maupun desa-desa yang ada di Tabanan mengetahui adanya Pararem Nomor 5 tahun 2020 tentang Pengaturan Pencegahan dan Pengendalian Gering Agung Covid-19 ini. Masyarakat juga mengetahui dengan jelas bawa di dalam Pararem Nomor 5 tahun 2020 memiliki sanksi-sanksi bagi masyarakat yag melakukan pelanggaran protocol kesehatan dan tidak mentaati jam malam yang telah ditentukan maupun kepada pelaku usaha yang tidak mematuhi peraturan jam operasinal usahanya dan juga tidak menerapkan protocol kesehatan. Masayarakat juga mengetahui bahwa dalam perarem ini sanksi yang dijatuhkan lebih banyak pengenaan sanksi denda.

Selanjutnya tim peneliti menanyakan pendapat masyarakat apakah menurut pantauan mereka masyarakat di Kota Tabanan mematuhi peraturan yang dituangkan dalam Pararem Nomor 5 tahun 2020 ini ? sebagian besar dari masyarakat menjawab bahwa masyarakat di sekitar Kota Tabanan masih banyak yang tidak mentaati aturan ini. Mereka merasa sanksi denda yang diatur dalam Pararem ini yaitu Untuk masyarakat yang tidak menggunakan masker akan didenda Rp 50 Ribu, untuk warung tradisional yang melanggar jam buka/tutup didenda Rp 100 ribu dan toko modern yang melanggar didenda maksimal $\mathrm{Rp}$ 
500 Ribu. Kemudian untuk warga yang bertamu tanpa tujuan yang jelas melewati jam akan didenda masing masing Rp 250 ribu baik tuan rumah maupun yang bertamu. Terakhir, masyarakat yang keluyuran lewat jam tanpa tujuan yang jelas akan didenda Rp 250 ribu (Aryawan, 2020), masih belum cukup membuat masyarakat mematuhi aturan tersebut. Padahal secara filsafat hal paling mendasar dari suatu hukum atau norma hukum adalah hukum atau norma haruslah dibuat untuk mendorong seseorang agar mau tunduk dengan hukum agar terciptanya ketertiban dalam masyarakat dan dijaminnya keamanan.

Hasil wawancara yang dilakukan tim peneliti juga menunjukan adanya keberatan dari masyarakat mengenai sanksi denda yang dijatuhkan dalam Pararem Nomor 5 tahun 2020 ini. Menurut masyarakat di masa pandemic covid19 membuat sebagian besar dari masyarakat terkena dampak yang sangat hebat karena tidak sedikit dari mereka "dirumahkan" oleh tempat mereka bekerja. Begitu pula dengan msyarakat yang berperan sebagai pelaku usaha tidak mengenal usaha yang termasuk skala besar, kecil, ataupun menengah juga merasakan dampaknya karena angka penjualan mereka semakin menurun bahkan tidak jaran yang dalam sehari mereka tidak mendapatkan hasil apa-apa. Menurut masyarakat keadaan mereka yang kesulitan ekonomi akibat masa pandemik yang tidak kunjung selesai terasa semakin berat dnegan ketentuan denda yang diterapkan oleh Pemerintah Kota Tabanan. untuk membiayai kehidupan mereka sehari-sehari saja mereka kesulitan ditambah lagi mereka harus membayar denda yang jumlahnya cukup banyak.

Seperti yang telah diuraikan pada pembahasan pertama yaitu tentang efektifitas hukum. Bahwa untuk mengukur apakah suatu aturan atau norma hukum efektif atau tidak dalam masyarakat harus dilihat dari dua unsur yaitu apabila suatu aturan hukum dimengerti dan ditaati oleh sebagian besar target yang menjadi sasaran ketaatannya maka akan dikatakan aturan hukum yang bersangkutan adalah efektif. Kesadaran hukum dan ketaatan hukum merupakan dua hal yang sangat menentukan efektif atau tidaknya pelaksanaan perundang-undangan atau aturan hukum dalam masyarakat. Dikaitkan dengan efktifitas Pararem Nomor 5 tahun 2020 di Kota Tabanan menurut hasil wawancara warga masyarakat melihat aturan ini terlihat tidak efektif karena menurut mereka walaupun masyarakat mengerti apa maksud dan sanksi dari perarem ini tetapi masih terlihat banyak yang melanggar. Tidak sedikit orangorang yang masih tidak menerapkan protokol kesehatan dengan tidak menggunakan masker dan ketentuan jam malam pun tidak begitu dihiraukan. Masih banyak juga terlihat café atau rumah makan yang penuh dan tidak ada jaga jarak sama sekali serta tidak mentaati jam malam operasional yang ditentukan.

Melihat masih banyaknya celah dalam peraturan hukum dalam hal ini Pararem Nomor 5 tahun 2020 tentang Pengaturan Pencegahan dan Pengendalian Gering Agung Covid-19 tim peneliti rasa haruslah dilakukan rekonstruksi dalam peraturan ini. Hal yang sangat signifikan perlu diubah adalah dari segi sanksi. Pembuat aturan harus lebih memikirkan sanksi yang tepat dijatuhkan karena sanksi adminsistratif yang sudah ada ternyata tidak cukup untuk memaksa masyarakat mematuhi peraturan ini. Selain sanksi adminsitratif yang dapat dijatuhkan masyarakat yang melanggar protocol kesehatan dapat pula dijatuhi sanksi kerja social.

Pemberian sanksi kerja sosial sudah terlebih dahulu dicetuskan dalam inpres nomor 6 tahun 2020 tanggal 4 agustus 2020 peningkatan disiplin dan penegakan hukum protokol kesehatan dalam pencegahan dan pengendalian corona virus disease 2019. Sesuai inpres ini pemerintah mengharapkan pemerintah pusat maupun daerah menetapkan peraturan yang memuat sanksi terhadap pelanggaran penerapan protocol kesehatan dalam pencegahan dan pengendalian Corona Virus Disease 2019 (COVID19) yang dilakukan oleh perorangan, pelaku usaha, pengelola, penyelenggara, atau penangung jawab tempat dan fasilitas umum. Saksi yang dihimbau untuk diterapkan adala berupa teguran lisa atau teguran tertulis, kerja social, denda administrative, atau penghentian atau penutupan tempat usaha.

Sebagai landasan menerapkan sanksi kerja social dapat kita lihat dari Peraturan Gubernur Daerah Khusus Ibukota Jakarta Nomor 41 Tahun 2020 tentang Pengenaan Sanksi Terhadap Pelanggaran Pelaksanaan Pembatasan Sosial Berskala Besar Dalam Peanganan Corona Virus Disease 2019 (COVID 19) di Povinsi Daerah Khusus Ibukota Jakarta yang mana dalam Pergub ini memuat beberapa sanksi, baik bagi perorangan, penyelenggara kegiatan/usaha, lembaga pendidikan, maupun tempat kerja. Khusus bagi perorangan, sanksi yang diterapkan 
berupa sanksi administratif teguran tertulis, "kerja sosial" berupa membersihkan fasilitas umum dengan menggunakan rompi, atau denda administratif paling sedikit Rp 100 ribu dan maksimal Rp 250 ribu.

Konstruksi sanksi kerja social dalam Pararem Nomor 5 tahun 2020 sejalan dengan tiga golongan yang dianut oleh sanksi adat yaitu sanksi yang berkaitan dengan harta benda (uang atau barang), disebut artha danda; sanksi yang berkaitan dengan nestapa jiwa atau fisik disebut dengan jiwa danda; serta sanksi yang berkaitan dengan upaya pengembalian keseimbangan alam gaib (niskala) disebut dengan panyangaskara danda. Sanksi kerja social yang dimaksud sejalan dengan jiwa danda.

Sanksi yang dapat diberikan selain sanksi adat adalah jiwa danda atau sanksi yang berkaitan dengan nestapa jiwa atau fisik. Sanksi ini dapat berupa kerja sosial yang sekiranya pantas diterapkan di Kota Tabanan adalah dengan cara melakukan kegiatan bersih-bersih di area tempat umum milik Desa adat di tempat si Pelanggar tinggal, seperti membersihkan Banjar, Lapangan Olahraga milik desa adat, serta Pura-Pura disekitar Desa Adat. Hal ini sejalan dengan pendapat masyarakat sekitar Kota Tabanan karena menurut mereka seseorang akan lebih memperhatikan aturan apabila sanksi yang diterapkan membawa efek kepada dirinya seperti rasa malu terhadap warga sekitar ketika ia melakukan sanksi kerja sosial tersebut.

Selain mengenai sanksi pada Perarem Nomor 5 tahun 2020 harus lebih merumuskan secara jelas hal-hal yang dikecualikan dalam perarem ini. Menurut Bendesa Adat Kota Tabanan I Gusti Ngurah Siwa Genta sanksi yang diterapkan dalam perarem ini sebenarnya bersifat fleksibel. Menurutnya bagi masyarakat yang keluar lewat pukul 22.00 WITA karena memiliki kepentingan mendesak ataupun pulang kerja tidak dikenakan sanksi tetapi yang dikenakan denda adalah masyarakat yang kedapatan keluar rumah lewat pukul 22.00 WITA tanpa tujuan jelas (Bali tribune,2020). Penguraian secara jelas dan rinci dalam suatu aturan dianggap perlu karena apabila tidak maka akan menimbulkan kekaburan norma.

Upaya merekonstruksi Perarem Nomor 5 tahun 2020 adalah langkah yang dapat diambil untuk mengatasi rendahnya kedisiplinan masyarakat untuk menerapkan protocol kesehatan. Sekedar himbauan dirasa tidak cukup untuk "memaksa" masyarakat mematuhi cara hidup new normal yang dicanangkan pemerintah demi memutus mata rantai penyebaran covid 19. Pemerintah selaku pembuat kebijakan harus dapat mengambil langkah antisipatif apabila produk hukum yang sudah ada tidak dapat mengatasi permasalahan karena apabila hal ini dilakukan pembiaran maka tujuan hukum yang sebenarnya tidak akan tercapai.

\section{IV.SIMPULAN}

Desa Adat Kota Tabanan telah mengikuti intruksi dari Gubernur untuk membentuk pararem terkait pencegahan Covid-19, yaitu Pararem Desa Adat Kota Tabanan Nomor 5 Tahun 2020 tentang Pengaturan Pencegahan dan Pengendalian Gering Agung Covid-19 yang mulai berlaku 1 September 2020. Dalam perarem tersebut, telah diatur sejumlah ketegasan seperti diantaranya denda untuk warga yang tidak menggunakan masker, melanggar jam buka/tutup warung tradisional dan toko modern, hingga bertamu lewat jam yang telah ditentukan. Untuk masyarakat yang tidak menggunakan masker akan didenda Rp 50 Ribu, untuk warung tradisional yang melanggar jam buka/tutup didenda Rp 100 ribu dan toko modern yang melanggar didenda maksimal Rp 500 Ribu. Kemudian untuk warga yang bertamu tanpa tujuan yang jelas melewati jam akan didenda masing masing $\mathrm{Rp} 250$ ribu baik tuan rumah maupun yang bertamu. Terakhir, masyarakat yang keluyuran lewat jam tanpa tujuan yang jelas akan didenda $\mathrm{Rp} 250$ ribu.

Melihat masih banyaknya celah dalam peraturan hukum dalam hal ini Pararem Nomor 5 tahun 2020 tentang Pengaturan Pencegahan dan Pengendalian Gering Agung Covid-19 tim peneliti rasa haruslah dilakukan rekonstruksi dalam peraturan ini. Hal yang sangat signifikan perlu diubah adalah dari segi sanksi. Pembuat aturan harus lebih memikirkan sanksi yang tepat dijatuhkan karena sanksi adminsistratif yang sudah ada ternyata tidak cukup untuk memaksa masyarakat mematuhi peraturan ini. Selain sanksi adminsitratif yang dapat dijatuhkan masyarakat yang melanggar protocol kesehatan dapat pula dijatuhi sanksi kerja social. Sanksi yang dapat diberikan selain sanksi adat adalah jiwa danda atau sanksi yang berkaitan dengan nestapa jiwa atau fisik. Sanksi ini dapat berupa kerja sosial yang sekiranya pantas diterapkan di Kota Tabanan adalah dengan cara melakukan kegiatan bersih-bersih di area tempat umum milik Desa adat di tempat si Pelanggar tinggal, seperti membersihkan Banjar, Lapangan Olahraga milik 
desa adat, serta Pura-Pura disekitar Desa Adat. Hal ini sejalan dengan pendapat masyarakat sekitar Kota Tabanan karena menurut mereka seseorang akan lebih memperhatikan aturan apabila sanksi yang diterapkan membawa efek kepada dirinya seperti rasa malu terhadap warga sekitar ketika ia melakukan sanksi kerja sosial tersebut.

\section{DAFTAR PUSTAKA}

Aryawan, I. M. P. (2020). No Title. Retrieved from bali.tribunnews.com/2020/09/01/mulai-hari-inidesa-adat-kota-tabanan-terapkan-sanksi-bagipelanggar-pararem-pengendalian-covid-19

H.S, S., \& Nurbani, E. S. (2013). Penerapan Teori Hukum Pada Tesis dan Disertasi. Jakarta: Rajawali Press.

Parwata, A, A, G. O. (2007). Memahami Awig-Awig Desa Pakraman. dalam I Ketut Sudantra dan AA. Gede Oka Parwata (ed): Wicara Lan Pamidanda, Pemberdayaan Desa Pakraman dalam Penyelesaian Perkara di Luar Pengadilan, Upada Sastra, Denpasar.

Soekanto, S. (2007). Pengantar Penelitian Hukum. Jakarta: Universitas Indonesia.

Sudantra, I. K., \& Windia, I. W. (2011). Penuntun Penyuratan Awig-Awig. Denpasar: Udayana University Press.

Utrecht. (1962). Pengantar Hukum Administrasi Negara Indonesia. Jakarta: Ichtiar.

Bali tribune, Sanksi Perarem Desa Adat Kota Tabanan Fleksibel, 03 September 2020

Bunga Rampai Asosiasi Pengajar Hukum Adat (APHA) Indonesia, 2020, Melihat Covid 19 Dari Perspektif Hukum Adar. Penerbit LSHI, Jakarta.

Jimly Asshiddiqie, e-book Konstitusi \& Konstitusionalisme Indonesia. 